\title{
“Oh, You Black Bottom!” Appropriation, Authenticity, and Opportunity in the Jazz Dance Teaching of 1920 s New York ${ }^{1}$
}

\author{
Danielle Robinson
}

Wead tossed back wearing a mile-wide grin, ecstatic arms stretched to the sky, jutting knees counterbalancing a substantial backside-the Jazz Age had no symbol more potent than the moving black body (Figure $\mathrm{I}$ ). Nearly always an illustration, and in many cases a caricature, these images depicted anonymous black movers rather than recognizable individuals. Yet, looking beyond this superficial representation, it was actually visibly white dance professionals who primarily marketed jazz steps to the American public as teachers and choreographers. A quick glance through the pages of the nascent Dance Magazine of the I920s reveals numerous jazz dance routines with names such as "High Yaller," "Pickin' Cotton," "The Savannah Stomp," and the "Hula-Charleston," each represented by a specific white Broadway performer (Fig. 2). Standing just behind each dancer, however, is a dark dancing figure that remains nameless and faceless. ${ }^{2}$ Although only a shadow, this image stands as a strong reminder of the numerous, unacknowledged black dance teachers who coached and choreographed for white Broadway-who supported the popular theater of this vibrant time in important ways, while also establishing a new profession for themselves and many others who followed.

Unlike the white ragtime dance teachers of the second decade of the twentieth century, who were also proffering "black" dancing to the public, African-American jazz teachers did not write manuals, open their own cabarets, or appear on sheet music covers. Rather, they had to remain "invisible" 3 — while they opened

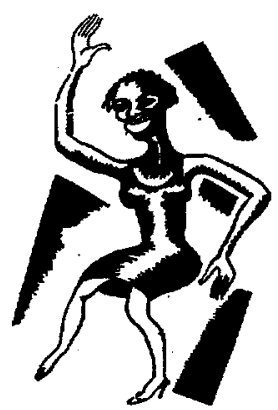

Figure I: An illustration by Everett $E$. Walsh for a 1927 magazine article. James E. Richardson. "Blame It on Jazz: King Fox Trot Joins the Immortals, "Dance Magazine, March 1927, 30. Used with permission.

Danielle Robinson, $\mathrm{PhD}$, is an assistant professor of dance studies at York University in Toronto, Canada, and a visiting professor in the graduate dance program of the Federal University of Bahia (UFBA) in Salvador, Brazil, where she team-teaches a seminar on dance cultural studies. She holds a doctorate from the University of California, Riverside, in dance history and theory and a master's degree from Northwestern University in theatre arts. 


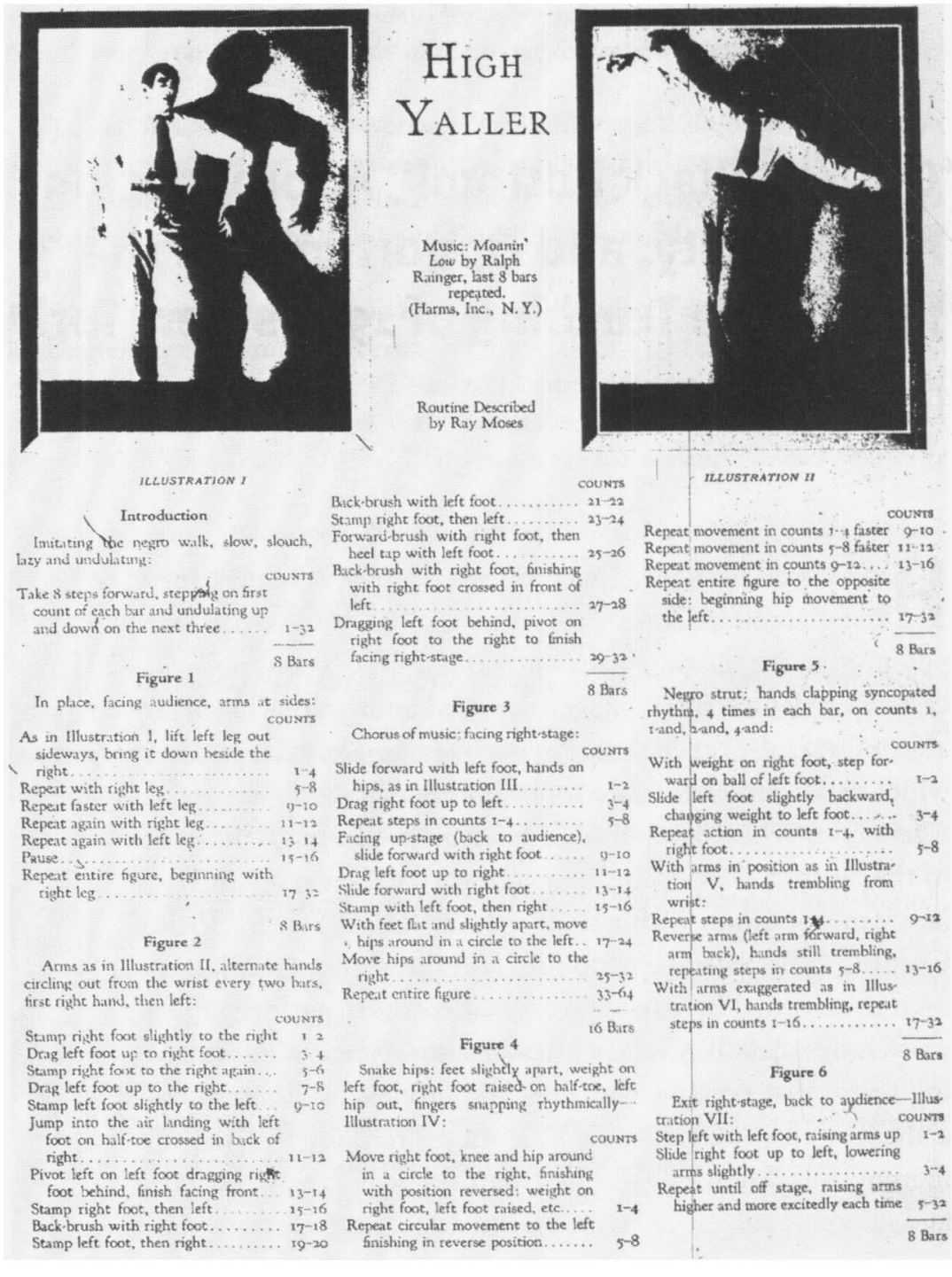

Figure 2: (facing pages) $A$ dance routine for readers to try at home. Ray Moses. "High Yaller: A Blues Number from The Little Show Conceived and Danced by Clifton Webb." Dance Magazine, October 1929, 30-3 I. Used with permission.

studios, gave lessons, taught routines, and choreographed for theaters and clubs all over Manhattan. In so doing, they developed new ways of working within the subordinating system of appropriation between black and white performers of the period.

In this article, I piece together a sense of black jazz dance teachers' lives and labors through extensive archival work and argue that their professional choices (their use of invisibility) were ultimately both empowering and disempowering to them. While carving out an important new profession and privately countering pervasive black stereotypes, their facilitation of an appropriative relationship and traffic in discourses of authenticity supported essentialist notions relating to black and white racial differences. For white 


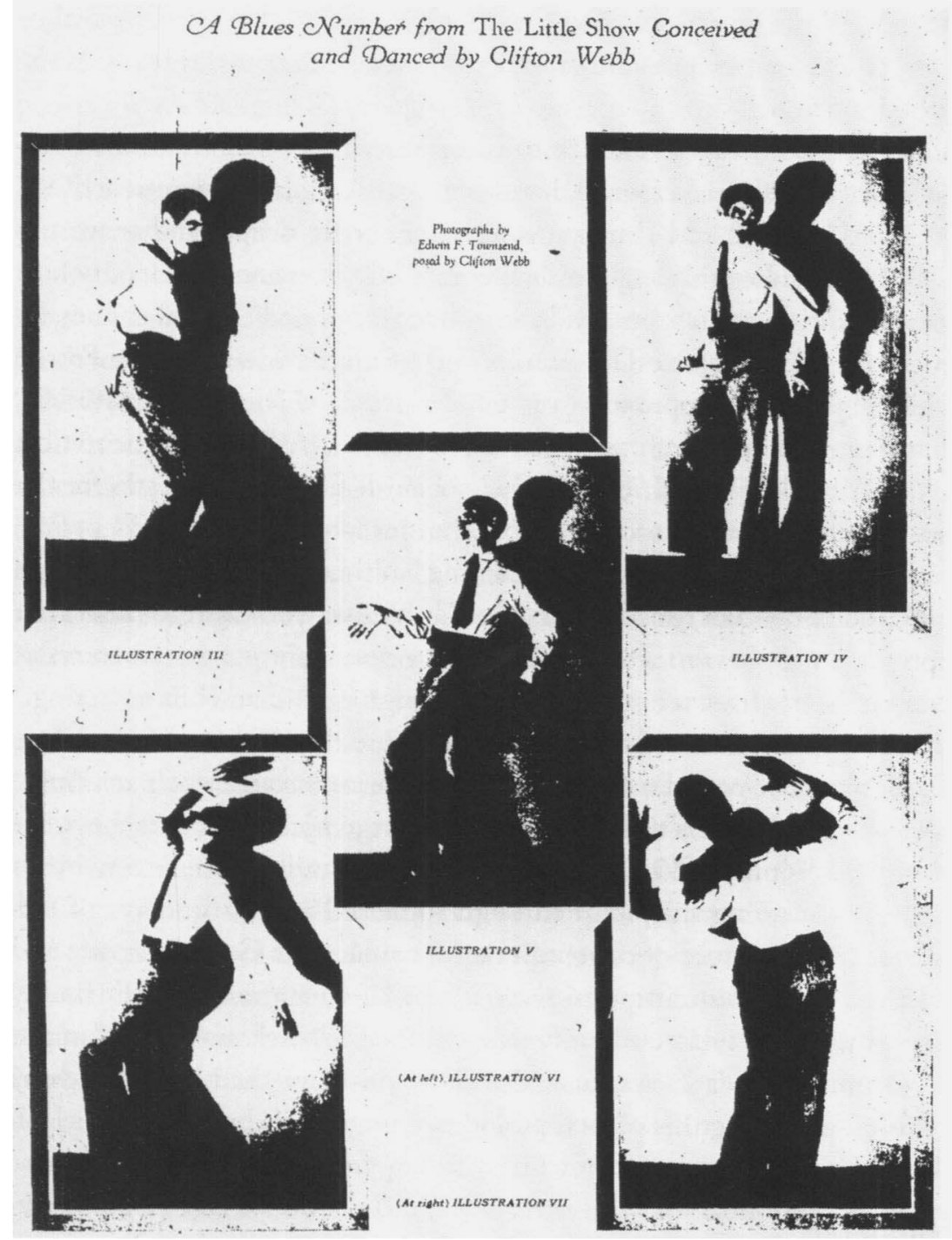

Americans, their work validated the pervasive belief that black bodies are an authentic source of emotion, bodily knowledge, and sensuality. ${ }^{4}$ Finally, in the process of launching this profession, black jazz teachers formalized a relationship between black and white dancers that reified the notion that black people, bodies, and dancing exist to support white pleasure and profit.

This project builds on the groundbreaking work of many scholars of African-American dancing, especially Brenda Dixon-Gottschild, Lynne Fauley Emery, Constance Valis Hill, Katrina Hazzard-Gordon, and Marshall and Jean Stearns. Unlike that of my predecessors, however, my work regards appropriation as a form of cultural work, as a practice that accomplishes things at a cultural level. Like the black jazz teachers, I choose to accept appropriation as a given, as part of their working conditions. I try to move beyond judgment in order to explore how it enabled particular changes to be made and allowed 
other conditions to remain the same. I ask, how did appropriative practices operate within New York City's entertainment worlds and cultural mosaic? And, how did black dance professionals respond to it?

In this project I rely most heavily upon historical research methods that have been honed by dance scholars over the past several decades. In particular, the rigorous archival work of Hazzard-Gordon, Hill, and Emery inspired me to dig deeply and creatively for bodily traces. I also have been strongly influenced by the questions of identity and representation pursued within contemporary dance ethnography and cultural studies, by authors such as Cynthia Novack, Jane Desmond, Marta Savigliano, and Susan Foster. In addition, Michel de Certeau's approach to popular culture, which blends historical, sociological, and ethnographic research perspectives, has been central to my theoretical framework. In his 1984 book, The Practice of Everyday Life, de Certeau advocates for the study of processes which determine socio-economic order alongside the ways people transform and manipulate such processes-conforming "to them only in order to evade them" (xiv). He calls these forms of resistance "tactics." In this way, de Certeau models an approach that represents people who are marginalized by dominant power structures as agents who quietly pursue their own empowerment through quotidian choice making.

After discussing the relevant historiography, I will situate the teaching of black jazz dancers within the contexts of period musical theater and prior instances of black dance teaching. I then focus on the studios that were founded by early jazz dance teachers, examine their working conditions, and interpret their labor tactics, in relation to writings on "black invisibility." Following this, I sift through some of the consequences of this new career path, with the assistance of contemporary race theorists George Lipsitz and J. Martin Favor. I then turn my attention to some of the surviving remnants of Buddy Bradley's choreography while I seek to identify what "authentic black movement" might have looked like on musical theater stages of the era and within the black Broadway studios that were founded during this pivotal period.

\section{Relevant Historiography}

The career of black dance teaching through paid lessons and private coaching, what I am calling the professionalization of black dance teaching, did not come to fruition until black dancers launched studios in the Broadway theater district of Manhattan at the height of the Jazz Age. ${ }^{6}$ There were certainly isolated incidents of formal dance teaching by black dancers prior to this point during the Cakewalk and ragtime dance crazes. But as I will discuss, these incidents did not constitute a defined career path.

During the I920s, the terms dance "coach" or "director" were much more common within New York's entertainment industries than "teacher" or "choreographer." I deliberately use the titles of teacher and choreographer in order to emphasize what their job entailed. I also use the term professional in order to highlight their decision to teach and choreograph as a career. In addition, I utilize the binary terms "black" and "white" in reference to people and dances because they were commonly used during the period, not because I view such constructions of racial identity or racial binaries as natural or 
accurate. Rather, in this article, I hope to problematize their construction through the teaching, marketing, and performing of jazz dancing. In these ways I hope to query the period hierarchies and distinctions between not only black and white dancing and dance professionals, but also between theatrical dance and so-called "popular" dance forms.

Although professional black dancers had worked in northern cities for more than a century, very few also earned income as teachers of African-American dancing. Prior to the $1920 s$, the very few African-Americans working as professional dance teachers taught European-American dances, not African-American dances. ${ }^{7}$ In fact, Manhattan's black teachers of white dancing formed a small professional organization in 1907 called "The Metropolitan Association of Dancing Masters." According to the Works Progress Administration (WPA) Federal Writers' Project, they taught dances such as "quadrille, schottische, polka, lancers, vauciviana [sic], and the prance" to New York's black elites (WPA, "Dancing Schools in Harlem," I). Before the I 920 , black dancing was rarely taught formally in either the black or white communities of New York City. Rather, dance steps and stylings were learned more casually through observation and participation at African-American religious, social, and familial gatherings. ${ }^{8}$

Within the humanities, black dance teachers, the teaching of black dancing, and the gradual professionalization of such teaching have received little scholarly attention. The lengthiest treatment is found in the Stearnses' Jazz Dance (r 968). These authors devote a chapter, entitled "Choreography: Buddy Bradley," to this black dance professional and the many others like him who also labored within Manhattan's Broadway dance studios. Their chapter discusses Bradley's choreographic process and tactics and provides several anecdotes from his relationships with white performers and productions. ${ }^{9}$ DixonGottschild's Waltzing in the Dark also mentions professional black dance teaching of the I $920 s$, albeit quite briefly. In the course of outlining the extreme racism at work within New York's twentieth-century entertainment world, she mentions several men whose dance teaching and choreography supported white Broadway shows and stars during the I 920 s without receiving any public credit for their contributions. In addition, Hill has presented a paper on Buddy Bradley's career in I 93 os London that delves primarily into his choreography (Hill 1992). Hill contends that Bradley moved to London to seek the credit and remuneration his work deserved but could not receive in Manhattan's theatrical environment.

For all of these authors, the issue of credit (or lack thereof) is addressed but dealt with quite differently. The Stearnses seem to regard the lack of credit afforded Bradley and his compatriots as more understandable than Hill and Dixon-Gottschild do. Jazz Dance's chapter on Bradley opens with an anecdote about a white dancer named Clifton Webb who took credit for Bradley's choreography in programs, press interviews, and magazine articles. The Stearnses write, "Did Webb remember Buddy Bradley? He did not mention him - but then neither would many others in the same position. ... Nobody saw anything wrong in such an arrangement. The coach had been paid" (Stearns I968, I60-6I). Their writing throughout this chapter emphasized the irony of white Broadway's being dependent on black dance teachers, rather than the inequities that resulted from this arrangement.

In contrast, Dixon-Gottschild and Hill comment directly on the injustice of white 
dancers taking credit for and profiting from black dancers' work. These authors were writing thirty years later, following the Black Power movements of the r97os, when dance scholarship was beginning to grapple with the erasures of black contributions to a variety of dance forms in America. In fact, Dixon-Gottschild's 1996 Digging the Africanist Presence in American Performance is still the most extensive work in this vein. Understandably, there was a great deal of anger expressed in such inquiries. A quote from Katrina Hazzard-Gordon's Jookin' exemplifies this:

Between 1877 and I920, African-Americans saw their music and dance adopted (poorly) by the white theater, the recording industry, and the newly emerging popular culture industry, while they suffered systemic exclusion from those markets. The songs of Mae West, Sophie Tucker, and 'Tin Pan Alley, Ann Pennington's black bottom, and the dances of Vernon and Irene Castle transformed black culture into something that white Americans could safely partake of. They led the white invasion of cabarets and the outright exploitive commercialization of African-American entertainment of the next three decades. (93)

Many scholars of black dance treated appropriation with abhorrence during the r 990 , not just Hazzard-Gordon. Although Dixon-Gottschild and Hill do not use language as strong as Hazzard-Gordon's, their writings likewise suggest that they have no patience for white dancers and producers succeeding at the expense of professional black dancers and teachers-even if it was an accepted practice at the time.

This particular view of appropriation may have actually prevented a more in-depth consideration of the black dance teaching of the 1920 . If appropriation is viewed in a way that black dancers are constructed simply as victims, then there is no motivation to look for ways in which many black dance professionals used the system of appropriation to their (limited) advantage when they began teaching the white representatives of jazz dancing. It would be almost impossible to reconcile the manner in which I 920 s black dance teachers were arguably complicit in their own exploitation, through a tactical formalization of an appropriative relationship via the Broadway studios, with a stance that is reliant on African-American performers being innocent victims of appropriation.

My work takes a position on appropriation that is somewhere in between the Stearnses and the I 990 s black dance scholarship of Hill, Hazzard-Gordon, and Dixon-Gottschild. I take very seriously the material ways in which a system of appropriation limited black performers' opportunities for career advancement. I also recognize the repercussions of an appropriation system that seemed to reinforce the longstanding view that black labor existed for white profit and pleasure. At the same time, I stress that appropriation launched the careers of teachers of black dancing. My work brings to light how some individuals found ways to work within an oppressive system to their advantage, albeit to less advantage than the white dancers they taught. Building on the work of these dance scholars, I inquire into the cultural work accomplished by appropriation.

In this study, I draw most heavily upon the research interviews conducted by early jazz writers Marshall and Jean Stearns with former professional black dancers during the middle 
of the twentieth century. ${ }^{\mathrm{IO}} \mathrm{I}$ put these perspectives alongside jazz-age media representations and promotional literature found in popular and dance periodicals of the era, such as the nascent Dance Magazine and the Tattler. The Tattler was a weekly magazine for Harlem's upper classes (and their aspirants), whereas Dance Magazine was a monthly for those who worked and aspired to work within Manhattan's entertainment world. These periodicals do not often mention I920s black dance teachers or their studios, but when they do, they offer exceptional information about these teachers' representations within different Manhattan venues. I also consulted the New York City Works Progress Administration Writers' Project manuscript papers, which contain a chapter on dance teaching. ${ }^{\text {I }}$ Finally, at times I quote from the historical writings of James Weldon Johnson, who, in addition to being a statesman and author, worked for a time within New York City's theater world during the early twentieth century. As an observer with a flair for language and extensive performance experience, his impressions provide an incisive perspective.

\section{Precursors}

In this section I suggest that the emergence of black dance teaching as a profession during the I 920 s was facilitated by the Jazz Age's overt embracing of "blackness" and the subsequent explosive growth of Manhattan's entertainment world. It was also foreshadowed by the sporadic teaching of black performers during the Cakewalk and ragtime dance crazes. ${ }^{22}$ It was not, however, prefigured by the teaching of European-American dances by African-American dance teachers. I have found no evidence to suggest a relationship between those teachers and the Broadway studio teachers I am discussing in this article.

More than any other factor, the superficial but overt embracing of "blackness" that occurred during the so-called Jazz Age established conditions for the success of professional black dance teaching. The black associations of jazz dancing and music did not need to be veiled, as they had been with ragtime; rather, they were celebrated. The "Negro" was now chic. Within New York City-which hosted the most developed theater business in the country - this meant that all-black musicals returned to Broadway theaters en masse and also that scores of downtown residents traveled uptown to patronize Harlem clubs that offered dancing and music by black performers. Indeed, there were more performing opportunities for black dancers during the i 920 s than ever before. ${ }^{13}$

But this alone was not what enabled the professionalization of black dance teaching. It was the even more plentiful performance opportunities for white dancers who could dance "jazz" that were the catalyst for this new profession. White jazz dancers, especially female ones, were the primary clients of the black Broadway studios, not professional black performers. Furthermore, it was white celebrity women who were most able to market black dances (such as the Shimmy, Charleston, and Black Bottom) directly to the American public through films, magazines, sheet music, and theater shows. Black dances, not black dancers, were the stars of the Jazz Age - a fact that may have limited the success of any visibly black dancers, while simultaneously enabling the careers of black dance teachers, working behind the scenes. 
While the combination of "Negritude" and Broadway created the possibility for the professional teaching of black dancing by generating an interest in putting explicitly black moves on white dancing bodies, emerging trends in the relations between black and white performers during earlier decades laid the groundwork upon which the studios were built. Indeed, there were antecedents to the professionalization of black dance teaching in two prior dance trends that introduced mainstream America to black social dancing-the Cakewalk craze of the 1890 s and the ragtime craze of the second decade of the twentieth century.

The late nineteenth-century Cakewalk provides the first evidence I have located of African-Americans teaching black dancing for pay. 'Their clients were the fashionable elite of New York City, such as Mr. and Mrs. William K. Vanderbilt, for whom learning to Cakewalk was an entertaining novelty (NAMCC 23 and Stearn, I 968, I 22). During this period, black professional dance teams, such as Charles Johnson and Dora Dean, and Bert Williams and George Walker, openly marketed the Cakewalk to America through sheet music and musical theatre performances. ${ }^{14}$

This practice was revived after I9 Io when the Turkey Trot, Bunny Hug, and Monkey Glide enraptured Manhattan's ragtime social dancers. Yet, the people who procured lessons in black dancing during this period were less likely to be white socialites like the Vanderbilts and more likely to be successful white professional dancers. Thus these lessons served not as entertainment but as professional development. The ragtime dance craze was also notably different from the Cakewalk craze because its primary representatives were white dancing teams (most notably Vernon and Irene Castle, and Maurice and Florence Walton), even though the dancing continued to be partially derived from African-American sources. ${ }^{15}$ As white dance teams rose to great heights of stardom from I 9 I 0 to I 920 , black performers receded into the background-relegated to Harlem theaters and segregated vaudeville circuits that paid far less than Broadway. James Weldon Johnson has poignantly described this period as "the term of exile of the Negro from the downtown theatres of New York"(Johnson I930, I 70). ${ }^{\text {I6 }}$

During the ragtime dance craze, which limited the financial success of black performers, the occasional lessons given by black professional dancers to white performers sometimes developed into ongoing relationships, what I will call private coaching. It is unclear, however, how widespread this practice was from r9 10 to r 920 . In her 1961 Stearns interview, Ethel Williams (a successful black dance professional of this era) remarked that after winning several dance contests around Manhattan and briefly performing at Bustanoby's cabaret in the Broadway theater district during I9 14, "Mrs. Castle [called at my home] and asked me to teach her some steps" (Williams I). Unfortunately, Williams does not go on to say if she accepted the offer, although it is possible that she passed this opportunity along to her dance partner Johnny Peters. According to Noble Sissle, a musician and composer who worked with the Castles, "the fellow who was responsible for inspiring Mrs. Castle and others was Johnny Peters." He explained, "Mr. and Mrs. Castle simplified some of these steps so that the society people could do them but they got much of it from [him]" (Sissle 6). Sissle's statements suggest that Peters, an African-American professional dancer, coached the Castles, the foremost white representatives of ragtime dancing.

Furthermore, Sissle's recollections suggest that the Castles were not the only profes- 
sional dancers that Peters coached, as evidenced by his phrase "Mrs. Castle and others." This statement indicates that the Castles' arrangement with Peters was not an isolated incident. Although scant evidence survives, it seems possible that the private coaching of white performers by black dancers actually began during the period I9IO-I 920 and that black dancers provided some of the ragtime dance craze's stars with their innovative steps. This teaching was not yet plentiful or lucrative enough, however, to support the opening of studios or a new career path for black professional performers.

Private coaching of professional white dancers by black dance teachers became commonplace by the mid-I 9205 - but not necessarily because of a dearth of performance opportunities for African-American dancers. Riding the wave of jazz's popularity in the early i 920 , black musical theater had returned to downtown theaters and black performers were achieving (limited) name recognition outside of black communities. Despite these advancements, black dancers did not directly market jazz dances to the American public through sheet music, newspaper articles, and theater programs as they had during the Cakewalk craze at the turn of the century. As far as the press was concerned, it was Ann Pennington's Black Bottom and Gilda Gray's Shimmy (two white Broadway stars), not Josephine Baker's or Ethel Williams'.

Thus, I contend that the teaching of black dancing grew into a sustainable profession because of the explosion of white Broadway shows, such as George White's Scandals and Florenz Zeigfeld's Follies, among many others. The contributions of black dance coaches remained in the background, however. I would argue this was because of growing black/white racial tensions, which were the result of increasing black migration into already crowded northern cities. According to United States Census data between r 9 ro and I930, New York City's African-American population almost quadrupled, primarily as a result of migration from the South that accelerated around I9I4. More than one hundred thousand migrants arrived between 1920 and r 930 alone. This influx led to an increase in informal and formal segregation practices (Douglas 3 I 4-I7). Many historians and sociologists have argued that I910-1930 was even more hyper-racialized and segregated than the prior decades as a result of increased migration and urbanization. ${ }^{17}$

\section{The Black Broadway Studios}

Black Broadway dance studios opened within a period of widespread interest in, and commercialization of, black dances but one that held comparatively limited opportunity for black performers. The studios seem to have emerged out of the private coaching that began during the ragtime craze and perhaps were inspired by the studios opened by white professional ballroom dancers from i 9 io to r 920 . Ned Wayburn's famous downtown studio, in its catering to Broadway stars and hopefuls, might have been an important model for the black Broadway studios. ${ }^{18}$ Ultimately, these studios provided a way for black dance teachers to coordinate their efforts and pool their resources, thus paving the way for the professionalization of black dance teaching.

Based on the sources I consulted, it is difficult to estimate the number of black dancers who transitioned to being teachers during the I 920s. Using the research of the Stearnses, 
Dixon-Gottschild, and the WPA Writers Project, I was able to identify nearly twenty of them, including Eddie Chavers, Buddy Bradley, Frank Harrington, Herbert Harper, Charlie Davis, Ernest Carlos, Mabel Horsey, Willie Covan, Lawrence Dees, Charlie White, Frank Montgomery, Addison Carey, Sammy Dyer, Leonard Reed, Leonard Harper, Elida Webb, John Bubbles, Clarence Robinson, and Roland Holder. The invisibility that was necessary for black dance professionals to make a living as teachers and choreographers in jazz-age Manhattan has unfortunately precluded many others from becoming a part of the historical record.

Financial backing was an absolute necessity for opening a dance studio in the downtown theater district of Manhattan. ${ }^{19}$ No performer, black or white, could have made enough money to set up and then sustain such a business as it grew over time. Even the Castles needed "society" backing to set up their Castle House, and they were the most renowned dancing couple of $1910-1920$.

The Stearnses suggest that author, arts patron, and socialite Carl van Vechten financed a Broadway dance studio (Stearns 134). Unfortunately, they do not explain the nature of the financial arrangement between van Vechten and the studio talent-that is to say, who was primarily profiting.

I suspect that van Vechten was not the only entrepreneur who viewed such studios as an investment opportunity. Black dance teaching was certainly a growth business during the 1920 s as white Broadway endeavored to mimic black Broadway's dancing style following the tremendous success of the black musical Shuffle Along from I 92 I to I 924. In addition, I speculate that individual Broadway theaters and producers may have had a hand in launching at least a few of the studios-especially given how much they had to gain by their presence in the downtown theater district-but I have not yet found evidence to support this hypothesis.

Based on the Stearnses interviews and the New York City WPA Writers Project, it seems that a dancer named Charlie Davis was among the first to open a Broadway studio that taught black dancing. Noble Sissle reported to the Stearnses that "[Davis] danced for years and then when white dancers tried to learn some of these dances, he opened a studio" (Sissle 3). His studio became a "haven for white dancers who wanted to learn black dances" (Stearns 1968, I 34).

While Davis's studio was among the first, the most successful of the teaching enterprises was opened by Billy Pierce in 1925 . It was Pierce who was memorialized by James Weldon Johnson's Black Manhattan of 1930. Johnson wrote,

Billy Pierce, though he is not on the stage and his influence has been exerted almost entirely through the white performer, cannot be omitted [from the historical record].... Mr. Pierce conducts a large and successful studio where he teaches dancers the art of tapping out intricate Negro rhythms with their feet. $(225)^{20}$

By the end of the 1920 , instructors who worked in Pierce's studio were coaching some of the best-known stars on Broadway, including Mae West, Gilda Gray, and Ann Pennington, and even Adele and Fred Astaire. They were also creating choreography for the most profitable Broadway revues, such as the Ziegfeld Follies, George White's Scandals, and the Greenwich Village Follies (Stearns I 968, I60-69). 
Contrary to Johnson's claims, Pierce actually did not dance or teach dancing; according to Thaddeus Drayton (one of the teachers at the studio), Pierce was more of an "impresario" (Stearns I 63). Drayton's clarification of Pierce's role suggests the manager/teacher model-that is, someone with business or management experience presiding over several dance teachers-may have internally structured the black Broadway dance studios. With regard to financial arrangements, Drayton told the Stearnses that Pierce split the revenues with his teachers (Drayton I). In their chapter on Bradley, the Stearnses claim that dance instructors at some schools were paid as little fifteen dollars per week, no matter how many routines they choreographed and or students they taught (Stearns I6o-69). By comparison, Pierce's arrangement with his teachers was quite generous.

Drayton mentions that Pierce hired only men at his studio. This is confirmed by Dixon-Gottschild, who says that "this was a male dominated profession," and Elida Webb was "one of the few women" (Dixon-Gottschild 2000, IO2). It is difficult to know why this was the case- why women were excluded from this new dance profession. Thus far I have found no evidence that explains the gender exclusivity of I 920 s black dance teaching. However, I suspect that having women in the studios-where they were hired by the hour for their physical expertise-would have seemed too much like prostitution and risked the legitimacy of the studios. ${ }^{21}$

One of Pierce's most popular teachers was Buddy Bradley. His extensive client list brought his studio much of its fame and income. In fact, we know more about him than any other black dance teacher of this period because of his extensive interviews with the Stearnses and successful career abroad-where his name was actually printed in the program and he was given public credit for his work. With Bradley we have the benefit of knowing many of the shows on which he worked, while we can only speculate about his compatriots who stayed in New York. Indeed, his archival trail offers a case study from which we can cautiously generalize about the experiences of other black dance teachers of this period, while keeping in mind he was much more successful than most.

Bradley, as part of his job at Picrce's studio, was hired to privately "coach" stars, what I am calling dance teaching, as well as to "group" scenes for musicals, what I choose to describe as choreography. In one of his numerous interviews with the Stearnses, he described his job simply: "They call me to patch them up," referring to shows (Stearns I 62). Periodical evidence suggests that he did much more than his humility implies, however. An advertisement in a 1927 Tattler announced to the elites of Harlem,

$$
\begin{gathered}
\frac{\text { W A N T E D }}{\text { I6 Peppy Brown Skin Girls }} \\
\text { Ziegfeld Productions-Long Broadway Run Assured } \\
\text { Free Dance Instructions by } \\
\text { Buddy Bradley }
\end{gathered}
$$

All Casting Under Personal Direction of Billy Pierce (Zeigfeld Productions)

This advertisement suggests that Bradley and Pierce—as well as possibly other I 920 s black dance teachers - worked closely with the Ziegfeld Follies and other big musical and revue producers such as Lew Leslie and George White, on both casting and choreography. 
This advertisement also suggests that Bradley, as well as many other black dance teachers of the I920s, were not just choreographic handymen who might be called upon to fix problems. They were choreographers in every sense except receiving credit in the program and a seat in the audience on opening night. This qualification implies that a key job requirement of I 920 black dance teachers was a tactical invisibility to white audiences-a fact that demonstrates the superficiality of the Jazz Age's celebration of "Negro chic."

Bradley's invisibility as a choreographer to the white theater-going public was only reinforced by his absence from the theater once the show opened. As Drayton once told the Stearnses, "They'd let [Bradley] rehearse and when the show opened he was out" (Drayton I). Although it is possible that Bradley "was out" due to his own hectic work schedule, Drayton's phrasing suggests a forced absence, perhaps due to a desire by producers to take full credit for Bradley's choreography, or due to their aversion to the show being associated with an actual African-American.

Of course, Bradley was not entirely invisible; he was simply not seen by white audiences. In Harlem and the Broadway theater district he was not only visible, but he was sought after for his expertise. The previously mentioned Tattler advertisement indicates that Bradley and Pierce had name recognition in New York's black communities despite their "invisibility" to Broadway audiences-otherwise Ziegfeld would have had no reason to name them in the advertisement. Furthermore, these men were well known in Broadway circles, as is made evident in Pierce's recurring advertisements in Dance Magazine during the late 1920 , which was at that time a periodical geared to a largely white clientele. For example (Fig. 3),

\author{
The Billy Pierce Studio \\ A School of Perfect Syncopated Rhythm \\ Creators of \\ Sugar Foot Strut, Black Bottom ... Tap Charleston, Devil Dance \\ Buddy Bradley and Frank Harrington \\ Masters (Billy Pierce Studio)
}

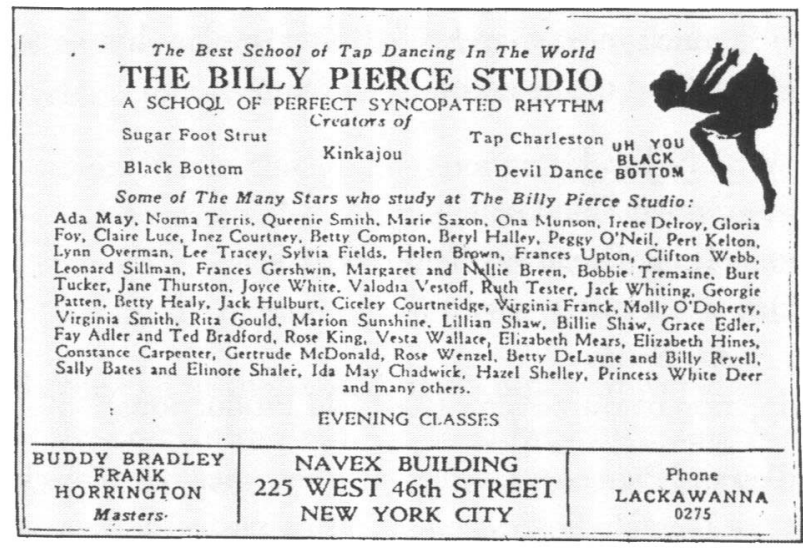

Figure 3: The December 1927 advertisement for the Billy Pierce Studio. "The Billy Pierce Studio," Dance Magazine, December 1927, 6. Used with permission. 
Such ads did not run every month, but once or twice a year. Nonetheless, they indicate that Billy Pierce and Buddy Bradley, as well as Frank Harrington it seems, were actually quite visible to aspiring and professional dancers, the primary consumers of Dance Magazine at that time.

\section{Invisible Men}

Professional black dance teachers were invisible only to the audiences who paid to see their work. But who required this? Whom did it benefit? Dixon-Gottschild offers us a theorization of invisibility within black American performance that is culled from her extensive research on twentieth-century theater and dance. She writes "the Africanist presence ... has suffered from sins of commission and omission; it has been invisibilized, to coin a new word" (Dixon-Gottschild r 996, 2-3). This author views invisibility as a choice on the part of white performers and producers-not black. Her language implies a deliberate pilfering and erasure of black contributions. She insinuates that black dance professionals are acted upon, rendered invisible by others who stand to profit from their labors.

Contrastingly, Ralph Ellison, who was living in Harlem during the r93os, attributes black invisibility to white observers. In his I 947 Invisible Man, he writes "I am invisible, understand, simply because people refuse to see me ... they see only my surroundings, themselves, or figments of their imagination - indeed, everything and anything except me" (Ellison 3). Ellison reminds us that not seeing can be a choice or a habit and is not always the result of erasure. Rather, his book describes the conditions-the white ignorance, the force of habit, and the white objectification and dehumanization of black people - that made the erasure of black contributions (and therefore people) possible. His definition of invisibility suggests how white audiences may have elected not to recognize the black men and women who contributed to the white jazz performances they were seeing, while at the same time acknowledging jazz dancing as a black phenomenon.

One could argue, how else could white jazz dancers have learned their craft? If they did not directly learn through lessons, then they certainly learned their moves through observation in black clubs or theaters. Mae West confessed as much in her autobiography that she learned the Shimmy in a club on Chicago's South Side where "big black men with razor slashed faces" congregated with "fancy high yellows and beginner browns" (West 64). There was inevitable contact with African-Americans somewhere-a fact, that many in the audience perhaps could not tolerate and therefore chose not to see, thus rendering black dance teachers invisible.

I would argue that the invisibility of 1920 s black dance teachers is attributable to audiences, performers, and producers-as Dixon-Gottschild and Ellison propose-but also to the teachers themselves. Since they could not change the racial politics of the time, these black men (and a select few women) needed their invisibility in order to launch and sustain their new careers. Indeed, I am suggesting that the very practice that limited their potential, invisibility, was used deliberately by black dance teachers to facilitate a new and much needed profession for African-Americans. 


\section{Impact of Professionalization}

While we cannot know the intentions of those who opened and worked in such studios-whether they were seeking monetary gain or greater respect within Manhattan's entertainment world, for example - we can explore the effects of the studios and the professionalization they enabled. The black Broadway studios made important interventions into a system of appropriation that had existed between black and white performers at least since the nineteenth century. First and perhaps foremost, the studio system required that compensation be paid. Prior to the I920s, it was common practice for white performers to visit clubs and theaters where, through observation, they could learn new dance steps without having to pay or credit the black dancers from whom they borrowed. While the Broadway studios did not necessarily stop this practice, they did formalize relationships between black and white dancers in a way that allowed black dancers to benefit from what had been a one-sided exchange. By opening studios, black dancers bettered their chances of being compensated for borrowings that were likely to occur anyway, without their consent. Furthermore, the income that dancers earned from teaching, regardless of the amount, had symbolic as well as financial significance. It recognized that black dance teachers had skills and knowledge that merited reward. On another level, financial compensation for coaching implicitly validated black dancers' sense of cultural ownership of jazz dancing. It is possible that this was a motive for opening Broadway dance studios, as indicated by Noble Sissle's comment about Charlie Davis who opened his dance studio "when white dancers tried to learn some of these dances" (Sissle 3 ).

The Broadway studios also facilitated the establishment of black dance teaching as a profession in its own right, as more than simply an ancillary source of income for performers. This is especially significant given the few professions available to AfricanAmericans at the time. By the same token, only a few African-Americans were officially recognized as "professionals" by census definitions. According to United States Census data from I 930 only 2 perceent of U.S. "Negroes," who were defined by just one drop of "Negro blood," were engaged in a "profession"-a designation that occupies the top of the employment classification structure and denotes not only financial remuneration but also the acquisition of skills and knowledge through training, the implementation of technical standards, and the practice of businesslike behavior in the workplace ( $I 5^{t h}$ Census ro-I 3; Webster's 9 19; OED Online). According to this document, the largest recognized professions among African-Americans in New York City in 1930 were "actors and showmen" and "musicians and teachers of music" ( $15^{\text {th }}$ Census I I 22-43). The more esteemed professions-law and medicine-welcomed relatively few African-Americans. Within this context, the professionalization of dance teaching augmented a very brief list of professions truly open to African-Americans in New York City during the r 920 . Over 80 percent of Manhattan's African-American population in I 930 was engaged in semiskilled and unskilled labor as domestic servants, elevator tenders, janitors, and laundry operatives, for example.

Furthermore, the professionalization of black dance teaching in many ways countered 
several prevailing black stereotypes of the period. Through the very nature of their business, the formal teaching of black dancing skills, instructors demonstrated that such skills were not natural, but rather they were learned. This countered prevailing assumptions that professional black dancers were displaying their natural talent rather than skills that were the result of years of training and practice. Moreover, the transformation of black dancers into teachers through the founding of this profession offered many people a line of work that was more associated with the mind rather than the body. In an era much like today, when the mind and body were thought of as separate and when mental labor was much more respected than physical labor, professional dance teaching created an alternative to the laboring body that was so strongly associated with African-Americans during this period.

These gains might not have been possible if black dance professionals had put their collective energy into stamping out appropriation altogether or demanding credit for their work. Of course, there was a price to be paid for the benefits of professionalization. Crucial here is the recognition that cross-racial appropriation, even if financially compensated and/or conducted in the spirit of artistic admiration, is frequently grounded in simplistic understandings of identity. This point is lucidly expressed by George Lipsitz, who has argued that "appropriation ... is dependent on and reiterative of stereotypical and essentialist notions of difference" ( 120 ). Put simply, appropriation underscores a boundary and a hierarchy between an imagined "us" and "them." This sense of fundamental difference is certainly reflected in the Stearnses interviews with I 920 jazz performers who repeatedly drew unequivocal distinctions between "black" and "white" dances and people, despite the hybridity within dance forms that they themselves describe.

Viewed through Lipsitz's lens, the choreography created by professional black dance teachers and performed by Broadway's white jazz dancers articulated essential differences between black and white. Acts of appropriation actually highlight differences while at the same time superficially demonstrating a degree of integration. ${ }^{22}$ On stage and in the studios, I am suggesting, appropriated movement practices represented and reinforced "natural" racial difference.

As described by the Stearnses and Hill, Buddy Bradley's choreographic style-which may be emblematic of other I 920 s black dance teachers-involved a synthesis of relatively simple tap combinations with theatricalizations of African-American social dance torso and limb movements in a way that was visually dynamic and rhythmically accented. The Stearnses call his work a "revolutionary simplification" of black vernacular dance (Stearns I 66); Hill, however, insisted that Bradley's simplifications of black dance steps for Broadway must not be misconstrued as a dilution of black dance-"Bradley's jazz dance wasn't whitewashed" (Hill, I 9923 3). Although certainly a form of simplified jazz dancing, the Stearnses and Hill both insist that Bradley's routines did not lose their "authenticity" as black dance, which likewise echoes period understandings of racial binaries decades later.

To my knowledge, no films of Buddy Bradley's choreography currently exist, so it is difficult to know what his choreography actually looked like or how he marketed it to other dance professionals. Thankfully, within Dance Magazine of this period, fragments 
of his choreography survive in the form of dance routines and steps that were written for readers to practice at home. One example does not actually have any reference to Bradley on the page. The routine is called "High Yaller," and it is posed by and credited to Clifton Webb, a white Broadway performer of the period who studied with Bradley (Stearns I 60-6 I). Webb is listed by Pierce and Bradley in a 1927 Dance Magazine advertisement for their studio as one of their notable students. When asked by a reporter sixteen years after the fact, however, Webb continued to claim authorship of the routine (Stearns I6I). Nonetheless, in their chapter on Bradley, the Stearnses assume that he was the author of this routine. Bradley, however, is not quoted making this claim in any of his surviving interviews with them. ${ }^{23}$ The other fragments of Bradley's choreography that I will examine were found in two related Dance Magazine articles called "Low Down Dancing" and "More Low-Down Dancing" (published just a few months apart) in which Bradley himself demonstrates the movements described. Importantly, he is not credited as the author of the article, but the authenticity of the dancing resides in the blackness of his body and in the reputation of Bradley and of Pierce's studio.

Interestingly, in all the examples, the choreography is marked directly and indirectly as "authentically black" through body and language. In the first example, Clifton Webb's "High Yaller" is given a name that references a person of mixed racial background who would have been considered black by period definitions. The images used to illustrate the dance routine draw attention to the hips and butt by keeping the hands close to these areas of the body. The poses carve out angular shapes through bent arms and legs and what we would now call "jazz hands." The text, not written by Webb, tells the readers to begin by "imitating the Negro walk, slow, slouch, lazy, and undulating." The movements described in the routine include: stamping, dragging, jumping, brushing, sliding, hip circling, finger snapping, hand clapping, and syncopation.

In comparison, "Low Down Dancing" and "More Low-Down Dancing" directly state that the routines are "Real Negro Steps" (Figs. 4 and 5 ). This claim is verified by the photographs used to illustrate the routines, which show Buddy Bradley himself. This might not seem remarkable, but during this period photographs of black men and women rarely were printed in Dance Magazine. Much more frequent were sketches, which at times drew upon the stereotypes entrenched by blackface minstrelsy. ${ }^{24}$ In these photographs, Bradley brings our attention to his hips and knees by putting his hands there and by thrusting his hips to the side, front, and back. The body shapes are angular, once again, although the jazz hands are a little less frequent. The text, of unknown authorship, describes sliding, stamping, hopping, jerking, hip swaying, finger wagging, eye rolling, and off-beat rhythms. The first article includes a text written by Elise Marcus that frames the steps and Bradley's pictures. In this, she summarizes the characteristics of "real Negro dancing" as originating on "plantations and levees" and having "the bent knees, the humorous hips, the raised hands, the angular arms."

Even though these were routines designed for Dance Magazine readers, I think the writings suggest how Buddy Bradley's choreographies (and that of other jazz dance teachers) were marked as "authentically black," in the studio and on the stage. They also 


\section{Low Down Dancing}

The Low Down on the Real Negro Steps

By ELISE MARCUS

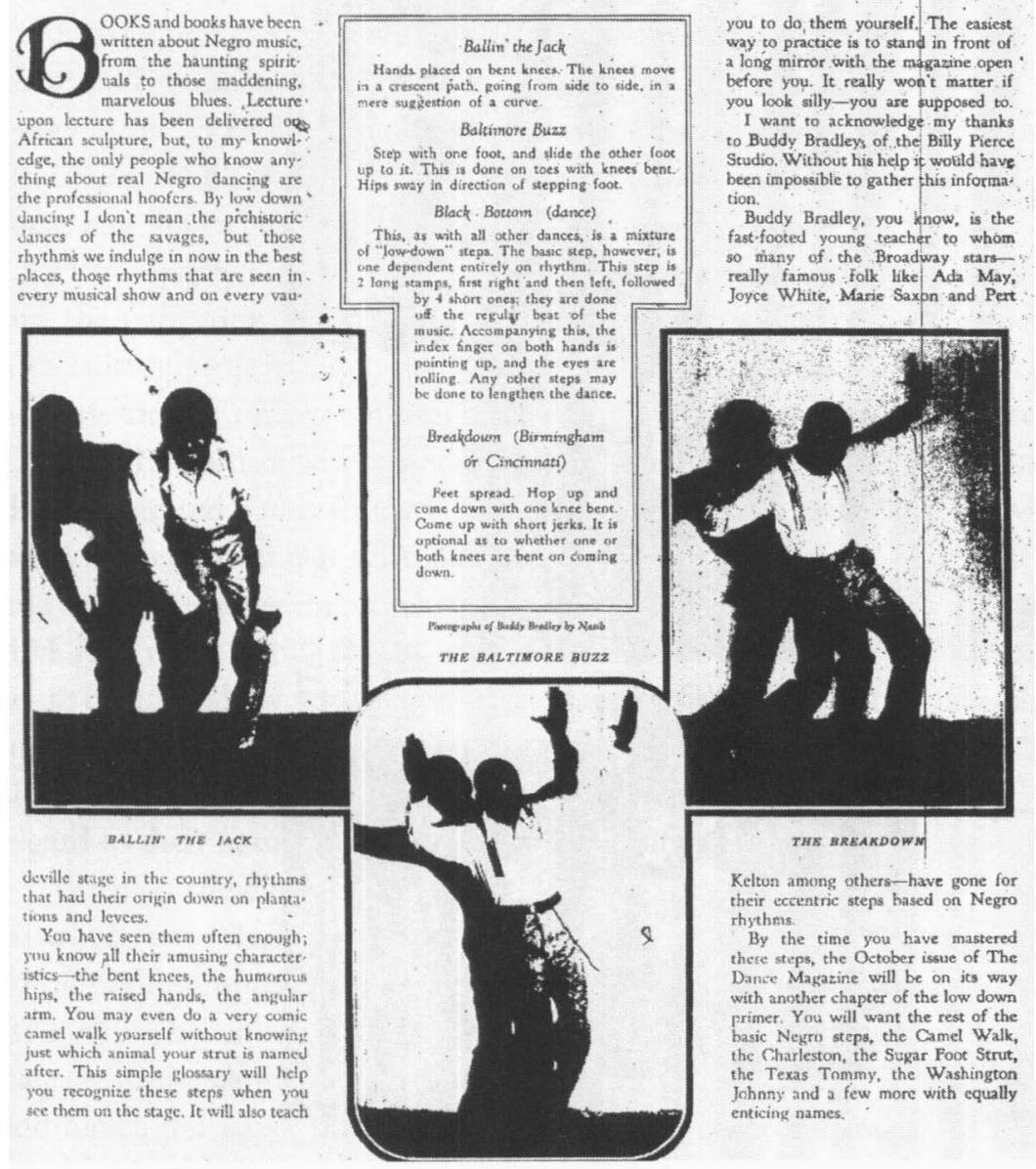

Figure 4: Elise Marcus, "Low Down Dancing: The Low Down on the Real Negro Steps, "Dance Magazine, September 1927, 38. Used with permission.

point out one way in which audiences were trained to "see" black authenticity-through magazine articles. Words such as Negro, low-down, and high yaller (or any other mulatto descriptive) identified the dancing as black, as did references to the South. Comparing the two routines, it seems that the movements that bring attention to the hips, create angular shapes, and highlight the hands also marked the dancing as black. Cross-referencing the routines, actions such as stamping, sliding, brushing, dragging hopping, jumping, slouching, undulating, and jerking suggested blackness. Hip articulations, sonic accents (such as snapping or clapping), and syncopated rhythms likewise marked the dancing as black. 


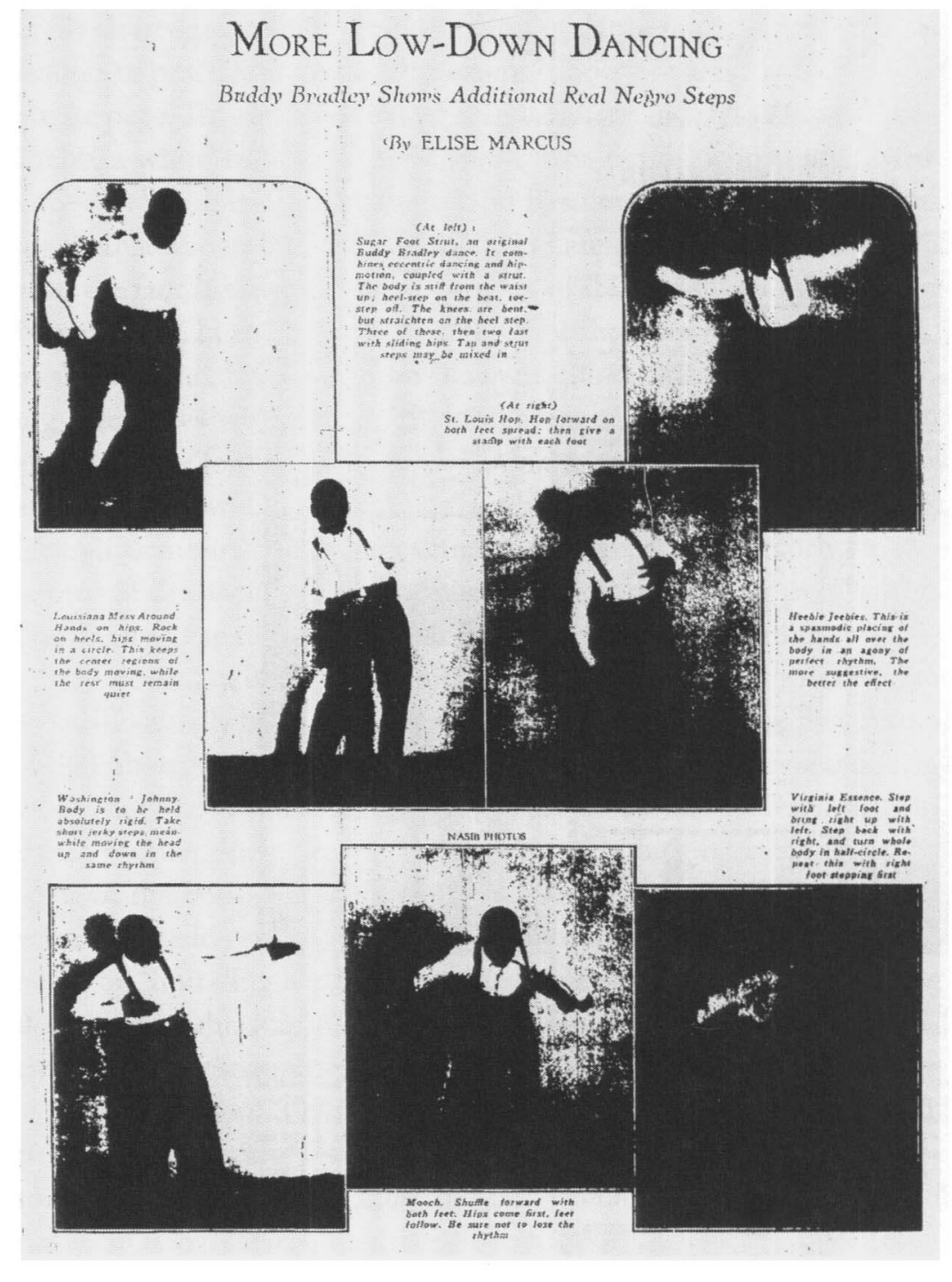

Figure 5: Elise Marcus, "More Low-Down Dancing: Buddy Bradley Shows Additional Real Negro Steps, "Dance Magazine, January 1928, 4I. Used with permission.

\section{Authentic Blackness in Motion}

While marketing their dance products drawing upon the selling points of the period, black jazz teachers also inadvertently commodified racial difference. Assertions of "authenticity," like appropriation, similarly underscores essential racial differences. As J. Martin Favor writes in Autbentic Blackness, authenticity is a notion that derives its power from a "system of similarity and difference" ( 1999,8 ). For period audiences, "authentic blackness" in jazz dancing likely signified a host of stereotypical notions-naturalness, wildness, exoticism, physicality, and sexuality. Even the white jazz dancers made racialist associations with their 
routines and teachers. Adele Astaire, Fred's sister and dancing partner, once said, "Oh, Buddy [Bradley] has taught me such marvelous, new, dirty steps" (Stearns I 64, 385 ng).

As a result, performances of appropriated, "authentic" black dancing promoted the recognition of racial differences between the dancer and the dance rather than the similarities. They highlighted the whiteness of the dancer and the blackness of the dancing. And, given that the white dancers were demonstrating their proficiency in black dancing, these performances can also be interpreted as an illustration of white mastery of black dancing and by extension a white mastery of black people and culture. In these ways, the invisibility of black dance teachers seems to have enhanced the visibility of essentialist ideas relating to racial difference.

While surely not an intended effect of the professionalization of black dance teaching, the reification of difference was a cost of black dancers' continued participation in a racialist appropriation system. Other responses by 1920 s black dances teachers, such as protesting or opting out, might have foreclosed a rare avenue for professionalization. Despite the hardships imposed by New York City's entertainment worlds, many black dancers located a way to work within it; in fact, they made their inevitable invisibility work to their advantage. Hidden from the white public eye, they launched a profession and sought empowerment within a system that seemed to guarantee their marginalization. As a result of this choice, they earned income, bolstered self-respect, and retained a sense of cultural ownership over black dancing. They carved out an avenue for their own upward social mobility as well as for those who would follow. In addition, their professionalization subtly challenged prevailing stereotypes about African-Americans with regard to their natural dancing ability and suitability for menial labor.

Without the cloak of invisibility, I doubt if these empowering countermoves would have been possible. Invisibility seems to have been the lynchpin in both the subordinating system of appropriation and the tactics black dance professionals used to challenge it. By looking beyond representations of Jazz Age performance, we can glimpse the black dancers whose clever improvisations led to the professionalization of black dance teaching and fueled the i 920 dance craze. Indeed, their choices stand as a strong reminder that within imposing structures of social power and systems of subordination lie crevices and crannies within which marginalized people express localized resistance and lay claim to empowerment in creative and courageous ways.

\section{Notes}

Since scholarship is a team sport (and since credit is a central theme of this article), I would like to thank Sally Ness, Deborah Wong, Anthea Kraut, Linda Tomko, and Sterling Stuckey for their important contributions to this research while it was part of my dissertation. Many thanks also to Ann Daly for her continuing mentorship and scholarly generosity. Without my esteemed dance colleagues, Roxane Fenton and Juliet McMains, this research would not have been possible. I am especially grateful to Jeff Packman for powerfully contributing to this work in its many, many iterations over the past several years (and geographic locations). Finally, to my new York University colleagues, special thanks for your heartfelt encouragement.

I. I draw the title of this article from a Pierce studio advertisement in Dance Magazine (see 
Fig. 3). An earlier version of this article won the 2004 Selma Jeanne Cohen Award for graduate research from the Society of Dance History Scholars. This work was supported by a Berger-Carter grant from the Institute of Jazz Studies at Rutgers University.

2. I would like to thank the panel audience members who pointed this out to me at the 2004 SDHS Annual conference at Duke University.

3. I am not the first in dance studies to apply this term to these dance professionals. See DixonGottschild (I 996, 2) and Hill ( 1992). The invisibility of black dance teachers and choreographers continues into the present day. Primary sources that testify to their labor are few. In fact, the sources that I most heavily draw upon in this article-research interviews conducted by Marshall and Jean Stearns more that fifty years ago-were found in 1999 in complete disarray at the bottom of archival boxes in the Institute of Jazz Studies at Rutgers University. The notion of black invisibility will be discussed at greater length later in the article.

4. Special thanks to Deborah Wong for pushing me to take this argument closer to the edge.

5. For a fuller treatment of the issue of black invisibility in American culture, please see DuBois, James Weldon Johnson, Gordon, Gibson, and Fontenot.

6. For a fuller discussion of the implications of such categorizations, please see DeFranz I 5 -I 7 .

7. See chapter five of Robinson for a discussion of the teaching of European-American dances by African-American dance teachers after the turn of the twentieth century.

8. For extended treatments of African-derived social dancing and its teaching in the United States, please see Emery, Stearns (1968), Dixon-Gottschild (2000, 2003), Hazzard-Gordon, Malone, and Krasner.

9. I use the word tactics here and elsewhere to reference de Certeau's distinction between strategies and tactics. To summarize, tactics are used by the disempowered, whereas as strategies are used by those in power to maintain their domination.

Io. The original research interviews conducted by Marshall and Jean Stearns over the course of three decades are partially preserved in the Institute for Jazz Studies, which they established at Rutgers University. By "partially preserved"I mean that the interviews are chronicled in fragments on handwritten scraps of paper and on hastily typed manuscript pages. I have thus far not found any sound recordings. In addition, the Stearnses seem to have only transcribed selections from their conversations with former performers. As a result, we cannot know the full context of interviewees' responses. Typically, they saved only the portion of the interviewee's responses that they deemed important at the time-which in many cases meant that a dance's place of origin was being discussed.

That said, the interview manuscripts are a rich resource for anyone doing research into black music and dance of the twentieth century. Contained within these pages are snapshots from performers' lives and careers. I use this information as a primary source that represents professional performers' experiences as pioneers of an emerging black entertainment industry. As I have processed these interviews, I have also kept in mind that there were extreme cultural differences between the Stearnses, a white academic couple, and their subjects of study who tended to be working-class African-Americans-a fact which may have shaped the kind and amount of information imparted.

I I. The research studies compiled by the New York City WPA Writer's Project entitled "Negroes of New York," along with their earlier drafts, are currently housed at the Schomburg Center for Research in Black Culture in manuscript form. Although some of the research conducted for this writing program drew from print sources, much came from extensive interviews with Harlem residents during the 1930 s, a strategy which infused these studies with vibrance and humanity.

Two of the many chapters in "Negroes of New York" are devoted exclusively to dance and music, but the writers primarily discuss concert dance and music rather than performance forms 
that were created as part of social practice. In addition, there is a section on religious worship that allocates space to the music and dance that were a vital part of black church events. Surprisingly, despite its emphasis on theatrical performance, the Harlem WPA project includes a chapter on teachers of social dance. The writers of this section interviewed African-American social dance teachers who were alive in the late 1930 ; several of whom had been teaching from I 9 ro through the r 920 . In fact, the recollections of some of these teachers actually date back to the turn of the century. Their testimony, as depicted by the WPA writers, sketches how social dancing and teaching changed over time in Manhattan's black communities - thus providing unique insiders' perspective absent from other source materials I have consulted.

A series of narrated research studies without remnants of interviews to consult, the WPA papers cannot be strictly viewed as primary sources. Nonetheless, I regard them as incredibly valuable secondary sources that were created temporally and geographically much closer to my subject of study than any other secondary source I use. They are not a typical secondary source either. The Harlem WPA research studies were not written by trained researchers but by Harlem writers (and aspiring writers) such as Ralph Ellison, who did not always seek out more than one source before reporting information as fact. To counteract the uneven accuracy of these writings, in most cases, I have tried to verify the information they provide with a different primary or secondary source. Even though not entirely accurate, these writings do offer researchers a window into how Harlemites were historicizing themselves and their experiences from a very short historical distance.

I 2. See chapters three and four of Robinson for a discussion of the "whitening" of ragtime dancing by "modern" social dance industry professionals.

I3. My information on black musical theater of this period is drawn from several secondary sources, most especially: Malone, Stearns (1968), Johnson ( 1930), and Riis. See also NAMCC, Lewis, Douglas, Emery, and Anderson.

I4. For a more in-depth discussion of Cakewalking and the black performers who popularized and marketed it, see Krasner and Riis.

I 5. During ragtime's popularity, the blackness of its music and dance was not openly acknowledged. Nonetheless, racial origins were indicated through references to the South, use of black dialect, and syncopated rhythms in the music as well as through angular body shapes, emphasis on hip movement, and mimicry of animals in the dancing. Please see chapters one through four of Robinson for a more in-depth discussion of the open secret of ragtime's black associations.

16. I primarily attribute the difference between the Cakewalk and Ragtime dance crazes, in terms of their representatives, to the differing length of time and reach of these practices. Cakewalking remained largely a theatrical dance and a "craze," whereas the ragtime dances became a part of social dancing practices across America for more than a decade. They constituted the first time that America was dancing "black," putting black dancing into white bodies on a mass scale. For this reason, ragtime's blackness was a much more potent topic and could not be as openly acknowledged, therefore black performers could not directly represent or market the ragtime dances.

I also attribute this difference to the fact that, during the Cakewalk craze, black migration had only just begun. Thus, it was not until the ragtime era that migration fueled black/white racial tensions-thereby preventing black dance professionals from representing ragtime dancing to the white American public, reminding ragtime dancers of the blackness of their own dancing. Moreover, the ragtime dances were purportedly "refinements" of black dancing, according to white dance professionals from I 9 IO-I920. Black dance steps in their "raw" form were considered too dangerous. Who better to tame ragtime's black dancing than white dance professionals? For a more in-depth assessment see Robinson, chapters three and four.

I 7. I consulted the following secondary sources in this area: Nasaw, Osofsky, Douglas, Johnson (1930), Anderson, Boyer, Johnson and Campbell, Lewis, Trotter, and Nash and Weiss. 
I 8. See Cohen-Stratyner's work on Ned Wayburn.

I 9. I do not want to suggest that black dance teachers could not have opened studios without the assistance of white financing. I did find anecdotal evidence of a dance studio owner working as a janitor in the building in exchange for studio rental. There might have been several innovative ways that cash-poor teachers found to keep their doors open until they built up their client base.

20. For an excellent study of tap dancing in America, see Hill (2000).

$2 \mathrm{I}$. Links between dance, women, and prostitution have been the impetus for anti-dance campaigns in Manhattan since the ragtime era. See the Committee of Fourteen, Investigators' Reports, and Perry.

22. This effect is much like that of American black-face minstrelsy. For further reading, see Roediger, Lott, Rogin, and Mizejewski.

23. In looking through the remaining interviews, I found no quote to this effect. It is likely that Bradley's authorship of "High Yaller" was something the Stearnses already knew (or was common knowledge) and therefore did not need to record in their interview notes.

24. Notable exceptions include a photo of Ethel Waters and one of Bill "Bojangles" Robinson.

\section{Works Cited}

Anderson, Jervis. I 982. This Was Harlem: A Cultural Portrait, I9oo- 1950. New York: Farrar, Strauss, and Giroux.

Billy Pierce Studio. 1927. Advertisement. Dance Magazine. December 6.

Boyer, Paul. 1978. Urban Masses and Moral Order in America, 1820-1920. Cambridge, Mass.: Harvard University Press.

Cohen-Stratyner, Barbara Naomi. I980. The Dance Direction of Ned Wayburn: Selected Topics in Musical Staging, I90I-1923. PhD diss. New York University.

Committee of Fourteen, Investigators' Reports. Records of the Committee of Fourteen, Rare Books and Manuscripts Division. New York Public Library. Astor, Lenox and Tilden Foundations.

De Certeau, Michel. 1984. The Practice of Everyday Life. Translated by Steven Rendall. Berkeley: University of California Press.

DeFranz, Thomas, ed. 2002. Dancing Many Drums: Excavations in African American Dance. Madison: University of Wisconsin Press.

Dixon-Gottschild, Brenda. 1996. Digging the Africanist Presence in American Performance: Dance and Other Contexts. Westport: Greenwood Press.

- 2000. Waltzing in the Dark: African American Vaudeville and Race Politics in the Swing Era. New York: Palgrave.

- 2003. Black Dancing Body: A Geography from Coon to Cool. New York: Palgrave Macmillan.

Douglas, Ann. I995. Terrible Honesty: Mongrel Manhattan in the I920s. New York: Noonday.

Drayton, Thaddeus. 1963. Typed manuscript of an interview with Marshall and/or Jean Stearns, Marshall Stearns Research Papers, Institute of Jazz Studies, Rutgers University. September 8.

DuBois, W. E. B. 1996. [1903.] The Souls of Black Folk. New York: Penguin Books.

Ellison, Ralph. I 947. Invisible Man. New York: Vintage Books.

Emery, Lynne Fauley. 1972. Black Dance in the United States from I6ro to I97o. Palo Alto, Calif.: National Press.

Favor,J. Martin. 1999. Authentic Blackness: The Folk in the New Negro Renaissance. Durham, N.C.: Duke University Press.

Fifteenth Census of the United States: 1930. 1933. Washington, D.C.: Government Printing Office. 
Fontenot, Chester J., Jr. 2003. 'Du Bois's 'Of the Coming of John,' Toomer's 'Kabnis,' and the Dilemma of Self-Representation." The Souls of Black Folk: One Hundred Years Later. Edited by Dolan Hubban. Columbia: University of Missouri Press.

Gibson, Donald. B. 1996. "Introduction." The Souls of Black Folk. Written by W. E. B. DuBois. New York: Penguin Books.

Gordon, Lewis R. I 997. "Existential Dynamics of Theorizing Black Invisibility." Existence in Black: An Anthology of Black Existential Philosophy. New York: Routledge.

Hazzard-Gordon, Katrina. I 990. Jookin': The Rise of Social Dance Formations in African-American Culture. Philadelphia: Temple University Press.

Hill, Constance Valis. I 992. "Buddy Bradley: The 'Invisible' Man of Broadway Brings Jazz Tap to London." In Proceedings of the ${ }^{5} 5^{\text {th }}$ Annual Conference, Society of Dance History Scholars: 77-84.

- 2000. Brotherbood in Rhythm: The Jazz Tap Dancing of the Nicholas Brothers. New York: Oxford University Press.

Johnson, Daniel M., and Rex R. Campbell. 198 I. Black Migration in America:A Social Demographic History. Durham, N.C.: Duke University Press.

Johnson, James Weldon. 1927. The Autobiograpby of an Ex-Colored Man. New York: Knopf.

-i 930. Black Manbattan. New York: Knopf.

Krasner, David. 1997. Resistance, Parody, and Double Consciousness in African American Theatre, I895-I9 10. New York: St Martin's.

Lewis, David Levering. 1 997. When Harlem Was in Vogue. New York: Penguin.

Lipsitz, George. 1998. The Possessive Investment in Whiteness: How White People Proft from Identity Politics. Philadelphia: Temple University Press.

Lott, Eric. 1993. Love and Theft: Blackface Minstrelsy and the American Working Class. New York: Oxford University Press.

Malone, Jacqui. 1 996. Stepping on the Blues: The Visible Rbythms of African American Dance. Urbana: University of Illinois Press.

Mizejewski, Linda. 1999. Ziegfeld Girl: Image and Icon in Culture and Cinema. Durham, N.C.: Duke University Press.

Nasaw, David. 1993. Going Out: The Rise and Fall of Public Amusements. New York: Basic Books.

Nash, Gary, and Richard Weiss, eds. I970. The Great Fear: Race in the Mind of America. New York: Holt.

National Afro-American Museum and Cultural Center (NAMCC). 1999. When the Spirit Moves: African-American Dance in History and Art. Edited by Barbara Glass. Wilberforce, Ohio: National Afro-American Museum and Cultural Center.

Osofsky, Gilbert. I996. Harlem: The Making of a Ghetto / Negro New York, I89o-1930. 2nd ed. Chicago: Ivan R. Dee.

Oxford English Dictionary Online. 1989. Second Edition. Oxford University Press. www.oed.com. Accessed April 2006.

Perry, Elizabeth. 1985."The General Motherhood of the Commonwealth: Dance Hall Reform in the Progressive Era." American Quarterly 37 (5): 719-33.

Riis, Thomas L. 1 989. Just Before Jazz: Black Musical Theatre in New York, I890-1915. Washington: Smithsonian Institution Press.

Robinson, Danielle. 2004. Race in Motion: Reconstructing the Practice, Profession, and Politics of Social Dancing, New York City 1900-1930. PhD Diss. University of California, Riverside.

Roediger, David. I 999. The Wages of Whiteness: Race and the Making of the American Working Class. Rev. ed. London: Verso.

Rogin, Michael. 1996. Blackface, White Noise: Jewish Immigrants in the Hollywood Melting Pot. Berkeley: University of California Press.

Sissle, Noble. I 96 I. Typed manuscript of an interview with Marshall and/or Jean Stearns, Marshall Stearns Research Papers, Institute of Jazz Studies, Rutgers University. September I 3. 
Stearns, Marshall and Jean. I 968. Jazz Dance: The Story of American Vernacular Dance. New York: Macmillan.

Correspondence, Manuscripts, Dance, and Personal Files. Marshall and Jean Stearns Research and Manuscript Papers at Institute of Jazz Studies, Rutgers University.

Thurman, Wallace. n.d. Negro Life in New York's Harlem: A Lively Picture of a Popular and Interesting Section. Girard, Kansas: Haldeman-Julius Publications.

Trotter, Joe William, ed. 1991. The Great Migration in Historical Perspective. Bloomington: Indiana University Press.

Webster's New Collegiate Dictionary. 1977. Springfield, Mass.: Merriam.

West, Mae. I959. Goodness Had Nothing to Do with It. Englewood Cliffs, N.J.: Prentice-Hall.

Williams, Ethel. r96r. Typed manuscript of an interview with Marshall and/or Jean Stearns, Marshall Stearns Research Papers, Institute of Jazz Studies, Rutgers University. Dec.

Works Progress Administration (WPA), Federal Writers' Project, New York (City). I 936-r 940.

"Negroes of New York." I 5 articles in one volume. Typescript portfolio. Schomburg Center for Research in Black Culture. New York, N.Y.

Ziegfeld Productions. I 927 . Advertisement, New York Tattler. 2 January: 9. 